\title{
KARAKTERISASI SIMPLISIA DAN EKSTRAK KULIT BATANG SEKILANG (Embelia borneensis Scheff.)
}

\author{
Risa Supriningrum ${ }^{1 *}$, Reksi Sundu ${ }^{1}$, Triswanto Sentat ${ }^{1}$, Eka Kumalasari ${ }^{2}$, \\ Rakhmadhan Niah ${ }^{2}$ \\ ${ }^{1}$ Sekolah Tinggi Ilmu Kesehatan Samarinda \\ ${ }^{2}$ Sekolah Tinggi Ilmu Kesehatan ISFI Banjarmasin \\ *Email: risa.stikesam@gmail.com
}

Artikel diterima: 05 April 2021; Disetujui: 22 September 2021

DOI: https://doi.org/10.36387/jiis.v6i2.677

\begin{abstract}
ABSTRAK
Tumbuhan sekilang (Embelia borneensis Scheff.) merupakan tumbuhan yang dimanfaatkan masyarakat Dayak menangkap ikan, pengusir lintah dan sebagai bahan perawatan rambut. Pemanfaatan tumbuhan secara empiris dapat dikembangkan menjadi suatu produk berbasis bahan alam. Tujuan penelitian adalah untuk mengetahui karakteristik spesifik dan non spesifik simplisia dan ekstrak kulit batang sekilang. Tahap penelitian meliputi determinasi tumbuhan, pengumpulan bahan baku, pembuatan simplisia, pembuatan ekstrak, uji organoleptik, uji mikroskopik, skrining fitokimia, penetapan kadar sari larut air, penetapan kadar sari larut etanol, penetapan kadar air, penetapan kadar abu total dan kadar abu tidak larut asam .

Hasil uji mikroskopi serbuk kulit batang sekilang menunjukkan adanya fragmen pengenal serabut sklerenkim, sel batu, kristal oksalat bentuk prisma. Kadar sari larut air rata-rata untuk simplisia dan ekstrak kulit kayu sekilang adalah 7,5\% dan $80 \%$. Kadar sari larut etanol rata-rata untuk simplisia dan ekstrak adalah $6 \%$ dan 30\%. Kadar air rata-rata untuk simplisia dan ekstrak adalah 9,5\% dan 12\%. Kadar abu total rata-rata untuk simplisia dan ekstrak $5 \%$ dan 8,5\%. Kadar abu tidak larut asam rata-rata untuk simplisia dan ekstrak adalah $1 \%$ dan $0,5 \%$.
\end{abstract}

Kata kunci: karakterisasi, Embelia borneensis, simplisia, ekstrak

\section{ABSTRACT}

The Sekilang plant (Embelia borneensis Scheff.) is plants used by the Dayak community for fishing, leech repellent and as an ingredient hair care. Empirical use of plants can be developed into products based on natural ingredients. The research was to determine the specific and non-specific characteristics of the simplicia and sekilang bark of extracts. The research stage includes plant determination, collection of raw materials, manufacture of simplicia, extract preparation, organoleptic, microscopic testing, phytochemical screening, determination of water soluble extract content, determination of ethanol soluble extract content, determination of water content and determination of ash content. Microscopy test results of sekilang stem bark showed the presence of fiber fragments, stone cells, and oxalate crystals. 
Jurnal Ilmiah Ibnu Sina, 6(2), Oktober 2021, 196-205

p-ISSN: 2502-647X; e-ISSN: 2503-1902

The average water soluble content for simplicia and sekilang bark extract was $7.5 \%$ and $80 \%$. The average ethanol soluble content for simplicia and extract was $6 \%$ and $30 \%$. The average moisture content for the simplicia and extract was $9.5 \%$ and $12 \%$. The mean total ash content for simplicia and extract was $5 \%$ and 8.5\%. The mean acid insoluble ash content for simplicia and extract was $1 \%$ and $0.5 \%$.

Keywords: characterization, Embelia borneensis, simplicia, extract

\section{PENDAHULUAN}

Lal B and Mishra N (2013) menyatakan ekstrak akar, daun dan buah dari spesies tumbuhan Embelia ribes memiliki aktivitas sebagai antimikroba dan antiprotozoa, analgesik, antiinflamasi, antioksidan. Jahidin dkk. (2014) melaporkan masyarakat Etnis Buton Keknauwe menggunakan rebusan kulit kayu dan daun Embelia ribes sebagai obat penyakit dalam. Penelitian yang dilakukan Rahayu dkk (2007) menyatakan bahwa tumbuhan Embelia sp (Ilang ketun) oleh suku Dayak Punan digunakan untuk perawatan rambut. Purwati dkk, (2020) menyatakan daun dari tumbuhan Embelia sp (Jembelu) oleh masyarakat Kutai Kartanegara Kalimantan Timur dimanfaatkan sebagai penambah citarasa pada masakan daging. Hasil skrining fitokimia menunjukkan ekstrak daun jembelu (Embelia $s p$ ) mengandung senyawa flavonoid, steroid, fenolik.

Suku Dayak Kenyah yang tinggal di desa Long Temuyat Kecamatan Kayan Hulu menggunakan kulit batang sekilang (Embelia borneensis Schiff) sebagai bahan untuk menangkap ikan dan pengusir lintah. Tumbuhan ini tumbuh di hutan Ampan Ibau, Malinau Kalimantan Utara. Kulit batang sekilang menimbulkan buih ketika dikocok ke dalam air sungai dan menyebabkan ikan mati, sehingga mudah ditangkap (Liman.D, 2019). Terbentuknya buih dapat dikaitkan dengan adanya kandungan senyawa saponin, yaitu senyawa metabolit sekunder yang apabila direaksikan dengan air dan dikocok, menimbulkan buih yang stabil.

Nurzaman dkk (2018) menyatakan saponin dapat menurunkan tegangan permukaan air, sehingga mengakibatkan 
Jurnal Ilmiah Ibnu Sina, 6(2), Oktober 2021, 196-205

p-ISSN: 2502-647X; e-ISSN: 2503-1902

terbentuknya buih pada permukaan air setelah dikocok. Saponin bersifat racun bagi hewan berdarah dingin, seperti ikan, karena dapat merusak insang dan hati ikan (Fisesa, 2017).

Karakterisasi meliputi dua parameter yaitu parameter spesifik dan parameter non spesifik. Parameter spesifik meliputi uji organoleptis, kandungan senyawa kimia metabolit sekunder, kadar sari larut air, kadar sari larut etanol dan parameter non spesifik diantaranya adalah kadar air, kadar abu total dan kadar abu tidak larut asam (Depkes RI, 2000). Penelitian ini bertujuan untuk mengetahui karakteristik simplisia dan ekstrak kulit batang sekilang.

\section{METODE PENELITIAN}

\section{Alat dan Bahan}

Alat yang digunakan yaitu alatalat gelas (pyrex), ayakan mesh 40, cawan porselen, krusibel, desikator, oven (Memmert), mikroskop , neraca analitik (Ohaus), maserator, tanur (carbolite) tangas air. Bahan yang digunakan kulit batang sekilang, aquades, asam klorida, asam sulfat, asam asetat anhidrat, amil alkohol, etanol, serbuk magnesium, pereaksi bouchardat, pereaksi mayer, perekasi dragendroff, besi (III) klorida, nhexane, kloralhidrat LP.

\section{Pengumpulan dan identifikasi sampel}

Sampel kulit batang sekilang diperoleh dari Hutan Ampan Ibau, desa Long Temuyat, Kecamatan Kayan Hulu, Kabupaten Malinau, Kalimantan Utara. Selanjutnya dilakukan identifikasi tumbuhan di Laboratorium Anatomi Fisiologi Tumbuhan Fakultas MIPA Universitas Mulawarman Samarinda.

\section{Pembuatan Simplisia}

Kulit batang sekilang yang telah dikumpulkan, dicuci, ditiriskan, dipotong-potong dan dikeringkan di bawah sinar matahari. Bahan yang telah kering, digiling, hingga diperoleh serbuk simplisia. Selanjutnya dihaluskan dan diayak dengan ayakan mesh 40 .

\section{Pembuatan Ekstrak}

Serbuk simplisia diekstraksi secara maserasi menggunakan pelarut etanol $70 \%$ dengan perbandingan 1:10, dilakukan pengadukan pada 6 jam pertama dan didiamkan selama 18 jam. Dilakukan penyaringan dan 
Jurnal Ilmiah Ibnu Sina, 6(2), Oktober 2021, 196-205

p-ISSN: 2502-647X; e-ISSN: 2503-1902

ampas dimaserasi kembali menggunakan pelarut yang sama. Semua maserat yang diperoleh diuapkan hingga diperoleh ekstrak kental (Kemenkes RI, 2017)

\section{Identitas sampel}

Identifikasi simplisia dan ekstrak bertujuan untuk memastikan bagian tumbuhan yang digunakan dan nama ilmiahnya (Depkes RI, 2000).

\section{Uji organoleptik}

Uji ini dilakukan dengan menggunakan panca indra, untuk mengetahui kekhususan bau, warna, rasa, dari serbuk simplisia dan ekstrak kulit batang sekilang. (Depkes RI, 2000).

\section{Uji mikroskopik serbuk simplisia}

Uji mikroskopik menggunakan mikroskop hingga diperoleh gambar yang jelas. Uji ini dimaksudkan untuk mengetahui fragmen pengenal pada serbuk simplisia kulit batang sekilang. Serbuk simplisia diletakkan pada gelas benda ditetesi dengan larutan kloral hidrat, ditutup dengan kaca penutup dan difiksasi di atas lampu spiritus. Selanjutnya diamati di bawah mikroskop dengan perbesaran tertentu. (Supomo dkk, 2016)

\section{Kadar Sari Larut Air}

Masing-masing sampel berupa serbuk simplisia dan ekstrak ditimbang 2 gram, dimaserasi dengan $100 \mathrm{ml}$ air kloroform dalam labu bersumbat, dikocok sesekali selama 6 jam pertama dan dibiarkan selama 18 jam, lalu disaring cepat. Sebanyak 20 $\mathrm{ml}$ filtrat pertama diuapkan di atas tangas air hingga kering dalam cawan dangkal yang telah ditara. Residu dipanaskan dalam oven pada suhu $105^{\circ} \mathrm{C}$ hingga diperoleh bobot tetap. Kadar sari larut air dihitung terhadap bahan yang dikeringkan di udara (Depkes RI, 2000; Depkes, 2008).

$$
\begin{gathered}
\text { Kadar Sari Larut Air }= \\
\frac{\text { berat sari }}{\text { berat ekstrak }} \times\left(\frac{100}{20}\right) \times 100 \%
\end{gathered}
$$

\section{Kadar Sari Larut Etanol}

Masing-masing sampel berupa serbuk simplisia dan ekstrak ditimbang 2 gram, dimaserasi dengan $100 \mathrm{ml}$ etanol 95\% dalam erlenmeyer, dikocok sesekali selama 6 jam pertama dan dibiarkan selama 18 jam, lalu disaring cepat. Sebanyak $20 \mathrm{ml}$ filtrat pertama diuapkan di atas tangas air sampai kering dalam cawan dangkal yang telah ditara. Dipanaskan sisa dalam oven pada suhu $105^{\circ} \mathrm{C}$ 
Jurnal Ilmiah Ibnu Sina, 6(2), Oktober 2021, 196-205

p-ISSN: 2502-647X; e-ISSN: 2503-1902

sampai diperoleh bobot tetap. Kadar sari larut etanol dihitung terhadap bahan yang dikeringkan di udara (Depkes RI, 2000; Depkes, 2008).

Kadar Sari Larut Etanol = $\frac{\text { berat sari }}{\text { berat ekstrak }} \times\left(\frac{100}{20}\right) \times 100 \%$

Identifikasi Senyawa Metabolit

\section{Sekunder}

Serbuk simplisia ditimbang sebanyak $2 \mathrm{~g}$ dan ekstrak sebanyak 0,5 g, dilarutkan masing-masing dalam campuran etanol-air (1:1), kemudian disaring. Filtrat digunakan untuk uji berikut (Harborne, 1987) :

\section{Uji senyawa alkaloid}

a. Pereaksi Mayer

Sebanyak 5 tetes filtrate ditambahkan 2-3 tetes $\mathrm{HCl} 2 \mathrm{~N}$ dan 2 tetes pereaksi mayer. Bila terbentuk endapan putih atau kuning menunjukkan adanya senyawa alkaloid.

b. Pereaksi Bouchardat

Sebanyak 5 tetes filtrate ditambahkan 2-3 tetes $\mathrm{HCl} 2 \mathrm{~N}$ dan 2 tetes pereaksi Baouchardat. Bila terbentuk endapan cokelat sampai hitam menunjukkan adanya senyawa alkaloid.

c. Pereaksi Dragendroff
Sebanyak 5 tetes filtrat, ditambahkan 2-3 tetes $\mathrm{HCl} 2 \mathrm{~N}$ dan 2 tetes pereaksi Dragendroff. Bila terbentuk endapan jingga sampai merah cokelat menunjukkan adanya senyawa alkaloid.

\section{Uji senyawa flavonoid}

Sebanyak $5 \mathrm{ml}$ filtrat, ditambahkan sedikit serbuk $\mathrm{Mg}$ dan asam klorida pekat $1 \mathrm{ml}$, amil alkohol 2 ml, dikocok dan dibiarkan memisah. Flavonoid positif jika terbentuknya warna merah, kuning, atau jingga pada lapisan amil alkohol (Harborne, 1987)

\section{Uji Senyawa Tanin}

Sebanyak 10 tetes filtrat, ditambahkan aquades hingga warna pudar, ditambahkan 1-2 tetes pereaksi besi (III) klorida, bila terbentuk warna biru kehitanman atau hijau kehitaman menunjukkan adanya senyawa tanin pada sampel tersebut (Atmoko dan Ma'aruf, 2009)

\section{Uji Senyawa Saponin}

Sebanyak 10 tetes filtrat, ditambahkan 5 tetes air panas, kemudian didinginkan, dikocok dengan kuat selama 10 detik. Jika 
Jurnal Ilmiah Ibnu Sina, 6(2), Oktober 2021, 196-205

p-ISSN: 2502-647X; e-ISSN: 2503-1902

terbentuk buih yang banyak selama 10 menit setinggi $1 \mathrm{~cm}$ sampai $10 \mathrm{~cm}$ dan tidak hilang dengan penambahan asam klorida $2 \mathrm{~N} 1$ tetes, maka menunjukkan adanya kandungan saponin (Depkes RI, 1989)

\section{Uji Senyawa Steroid/Terpenoid}

Ditimbang sampel serbuk $1 \mathrm{~g}$ dan ekstrak 0,5 g, masing-masing dimaserasi dengan $20 \mathrm{ml} \mathrm{n}$-heksan hingga terendam, selama 1 jam kemudian disaring. Filtrat yang diperoleh diuapkan lalu ditambah asam asetat anhidrat 2-3 tetes dan asam sulfat pekat 1-2 tetes. Jika terjadi perubahan warna menjadi merah atau ungu menunjukkan adnya senyawa terpenoid dan selanjutnya apabila terjadi perubahan warna menjadi hijau atau hijau kebiruan menunjukkan adanya steroid (Marjoni, 2016).

\section{Karakterisasi Non Spesifik}

\section{Simplisia dan Ekstrak}

Masing-masing sampel serbuk simplisia dan ekstrak ditimbang sebanyak $2 \mathrm{~g}$, ditempatkan dalam cawan porselen yang telah ditara sebelumnya, kemudian dioven pada suhu $105^{\circ} \mathrm{C}$ hingga diperoleh bobot tetap (Depkes RI, 2000; Depkes, 2008).

$$
\text { Kadar Air }=\frac{b-(c-a)}{b} \times 100 \%
$$

Keterangan :

$\mathrm{a}=$ berat cawan yang sudah konstran

$\mathrm{b}=$ berat sampel awal

$\mathrm{c}=$ berat cawan dan sampel kering yang sudah konstan

\section{Penetapan Kadar Abu Total}

Masing-masing sampel serbuk simplisia dan ekstrak ditimbang sebanyak $2 \mathrm{~g}$, dimasukkan ke dalam krus silikat yang telah dipijarkan dan ditara. Dipijarkan hingga habis pada suhu $600^{\circ} \mathrm{C}$ selama 3 jam kemudian didinginkan, ditimbang. Jika cara ini tidak dapat menghilangkan arang, ditambahkan air panas, disaring abu menggunakan kertas saring. Dipijarkan sisa dan kertas saring dalam krus yang sama. Dimasukkan filtrat ke dalam krus, uapkan, dipijarkan hingga bobot tetap, lalu ditimbang. Dihitung kadar abu terhadap bahan yang telah dikeringkan di udara (Depkes, 2000; Depkes , 2008).

$$
\begin{gathered}
\text { Kadar } \mathrm{Abu}= \\
\frac{\text { berat abu (g) }}{\text { berat simplisia (g) }} \times 100 \%
\end{gathered}
$$


Jurnal Ilmiah Ibnu Sina, 6(2), Oktober 2021, 196-205

p-ISSN: 2502-647X; e-ISSN: 2503-1902

\section{Penetapan Kadar Abu Tidak Larut}

Asam

Abu yang telah diperoleh dari hasil penetapan kadar abu didihkan dengan $25 \mathrm{ml}$ asam klorida encer selama 5 menit. Dikumpulkan bagian yang tidak larut asam, disaring melalui kertas saring bebas abu yang telah diketahui beratnya, dipanaskan dan kemudian didinginkan sampai diperoleh bobot konstan. Dihitung kadar abu yang tidak larut dalam asam terhadap bahan yang telah dikeringkan di udara (Depkes RI, 2000).

Kadar Abu tidak larut Asam =

$$
\frac{\text { berat abu }(\mathrm{g})}{\text { berat simplisia }(\mathrm{g})} \times 100 \%
$$

\section{HASIL DAN PEMBAHASAN}

Determinasi

tumbuhan

dilakukan di laboratorium Anatomi Fisiologi Tumbuhan Fakultas MIPA Universitas Mulawarman, Samarinda dan diperoleh hasil, nama latin tumbuhan Embelia borneensis Scheff, bagian yang digunakan adalah kulit batang dengan nama daerah sekilang. Penelitian tentang tumbuhan ini belum pernah dilaporkan, hanya sebatas penggunaan secara empiris.

Serbuk simplisia dan ekstrak etanol kulit batang sekilang menunjukkan hasil negatif pada uji steroid/terpenoid. Analisis senyawa steroid dan terpenoid didasarkan pada kemampuan senyawa tersebut membentuk warna dengan asam sulfat pekat dalam pelarut asam asetat anhidrat (Ciulei, 1984).

Prinsip uji alkaloid adalah reaksi pengendapan karena adanya penggantian ligan. Atom nitrogen pada alkaloid memiliki pasangan elektron bebas, sehingga dapat mengganti ion iod dalam pereaksi mayer dan dragendroff (Astarina dkk, 2013). Hasil uji senyawa tanin yang terdapat di dalam simplisia dan ekstrak kulit batang sekilang adalah positif, yang ditandai dengan terbentuknya warna hijau kehitaman pada penambahan larutan $\mathrm{FeCl}_{3}$ dan merupakan tanin terkondensasi.

Simplisia dan ekstrak etanol kulit batang sekilang menunjukkan hasil positif pada uji flavonoid, yang ditandai dengan terbentuknya warna kuning pad lapisan amil alkohol. . Simplisia dan ekstrak kulit batang 
Jurnal Ilmiah Ibnu Sina, 6(2), Oktober 2021, 196-205

p-ISSN: 2502-647X; e-ISSN: 2503-1902

sekilang membentuk busa stabil pada

Adriani (2010) tumbuhan yang saat dikocok dengan air. Saponin mengandung senyawa metabolit adalah senyawa yang bersifat aktif permukaan dan dapat menimbulkan sekunder saponin, flavonoid, alkaloid busa apabila dikocok dalam air memiliki aktivitas antibakteri dan (Kristiani dkk, 2008). Menurut antioksidan.

Tabel 1. Hasil Uji Organoleptik Kulit Batang sekilang

\begin{tabular}{llll}
\hline No & Parameter Uji & Serbuk simplisia & Ekstrak \\
\hline 1 & Warna & Coklat & Coklat \\
2 & Bau & Tidak berbau & Tidak berbau \\
3 & Rasa & Agak pahit & Agak pahit \\
4 & Bentuk & Serbuk & Kental \\
\hline
\end{tabular}

Tabel 2. Hasil Skrining Fitokimia Kulit Batang Sekilang

\begin{tabular}{llcc}
\hline No & Parameter Uji & Serbuk simplisia & Ekstrak \\
\hline 1 & Alkaloid & + & + \\
2 & Saponin & + & + \\
3 & Tanin & + & + \\
4 & Steroid/ & - & - \\
& terpenoid & & \\
\hline
\end{tabular}

Tabel 3. Hasil Penetapan Kadar Kulit Batang Sekilang

\begin{tabular}{|c|c|c|c|}
\hline No & Parameter Uji & $\begin{array}{c}\text { Serbuk simplisia } \\
\chi \text { Kadar }(\%)\end{array}$ & $\begin{array}{c}\text { Ekstrak } \\
\chi \text { Kadar } \\
(\%)\end{array}$ \\
\hline 1 & Sari larut air & 7,5 & 80,0 \\
\hline 2 & Sari larut etanol & 6,0 & 30,0 \\
\hline 3 & Kadar air & 9,5 & 12,0 \\
\hline 4 & Kadar abu total & 5,0 & 8,5 \\
\hline 5. & $\begin{array}{l}\text { Kadar abu tidak } \\
\text { larut asam }\end{array}$ & 1,0 & 0,5 \\
\hline
\end{tabular}

Kadar sari larut air pada serbuk simplisia dan ekstrak menunjukkan hasil yang lebih besar dibandingkan kadar sari larut etanol. Hal ini berarti bahwa sebagian besar senyawa metabolit sekunder dalam kulit batang sekilang lebih mudah larut dalam pelarut yang bersifat polar.
Kadar air simplisia kulit batang sekilang memenuhi syarat mutu yaitu $\leq 10 \%$, sedangkan kadar air ekstrak $>$ 10\%. Ekstrak kental memilki kadar air antara 5 -30\% (Mustarichi dkk, 2011). Penentuan kadar air juga terkait dengan kemurnian ekstrak. Kadar air yang tinggi $(>10 \%)$ berpotensi menyebabkan tumbuhnya 
Jurnal Ilmiah Ibnu Sina, 6(2), Oktober 2021, 196-205

p-ISSN: 2502-647X; e-ISSN: 2503-1902

mikroba yang akan menurunkan stabilitas simplisia ataupun ekstrak (Isnawati \& Arifin)

Abu adalah oksida logam yang merupakan residu pembakaran. Penetapan kadar abu bertujuan untuk mengetahui kandungan senyawa anorganik total dalam bentuk oksida logamnya. (Guntari dkk, 2015). Saifudin dkk (2011) menyatakan tujuan penetapan kadar abu adalah untuk menentukan karakteristik sisa kadar abu non organik setelah pengabuan. Setiap tanaman memiliki sisa abu secara spsifik.

Pengamatan secara mikroskopi dimaksudkan untuk mengetahui fragmen pengenal pada serbuk simplisia kulit batang sekilang. Hasil pengamatan menunjukkan, serbuk simplisia kulit batang sekilang memiliki fragmen pengenal berkas pengangkut, sel batu, kristal oksalat bentuk prisma dan serabut.

\section{KESIMPULAN}

Simplisia dan ekstrak kulit batang sekilang mengandung senyawa alkaloid, saponin, tannin, flavonoid. Kadar sari larut air pada simplisia dan ekstrak lebih besar daripada kadar sari larut etanol. Kadar air simplisia memenuhi standar, sedangkan pada ekstrak tidak memenuhi standar.

\section{UCAPAN TERIMA KASIH}

Terimakasih kepada Sekolah Tinggi Ilmu Kesehatan Samarinda yang telah mendanai penelitian ini.

\section{DAFTAR PUSTAKA}

Astarina, N., Astuti, K.W, Warditiani, N.K., (2013). Skrining Fitokimia Ekstrak Metanol Rimpang Bangle (Zingiber purpureum Roxb.). Jurnal Farmasi Udayana 2 (4).

Ciulei, J. (1984). Metodology for Analysis of Vegetables and Drugs. Bucharest Rumania: Faculty of Pharmacy. Pp. 1126.

Depkes RI. (2000). Parameter Standar Umum Ekstrak. Jakarta: Depkes RI

Kemenkes RI. (2008). Farmakope Herbal Indonesia Edisi I, Jakarta: Depkes RI

Erni Dian Fisesa. (2017). Pemberian Air Perasan Daun Dewa (Gynura procumbens) Dengan Dosis Yang Berbeda Terhadap Kelulushidupan Benih Ikan Nila (Oreochromis niloticus) Jurnal Pionir 2 (3), LPPM Universitas Asahan

Guntari Ayu, Sholehah. K, Irna.N, Fistianingrum. W. (2015). Penentuan Parameter Non 
Jurnal Ilmiah Ibnu Sina, 6(2), Oktober 2021, 196-205

p-ISSN: 2502-647X; e-ISSN: 2503-1902

Spesifik Ekstrak Etanol Kulit Buah Manggis (Garcinia mangostana) Pada Variasi Asal Daerah. Jurnal Farmasains, 2 (5): 204

Harborne. J.B. (1987). Metode Fitokimia Penuntun Cara Modern Menganalisis Tumbuhan. Bandung: Penerbit ITB. Hal: 82, 147.

Isnawati, A., Arifin, KM. (2006). Karakterisasi daun kembang sungsang (Gloria superba L.) dari aspek fitokimia. Media Litbang Kesehatan. 16(4):8-14

Jahidin, Maronta, La., Galib, Muzuni. , Damhuri. (2014). Ethnic Study of Traditional Medicinal Plants of Buton. Jurnal Sainsmat, III (1): 90-108

Kemenkes RI. (2017). Farmakope Herbal Indonesia Edisi II. Jakarta: Direktorat Jendral Kefarmasian dan Alat Kesehatan.

Lal B and Mishra N. (2013). Importance of Embelia ribes: An Update. Int J Pharm Sci Res: 4(10); 3823-3838

Liman, D. (2019). Wawancara tentang Pemanfaatan Kulit Batang Sekilang, Desa Long Temuyat Kecamatan Kayan Hulu, Malinau, Kalimantan Utara.

Marjoni, M. (2016). Dasar-Dasar Fitokimia. Jakarta: CV. Trans Info Media. Hal: 5-13.

Mustarichie R., Mustiroh, I dan levita, J., (2011). Metode Penelitian Tanaman Obat Cetakan
Pertama, Bandung: Widya Padjadjaran.

Nurzaman, F., Djajadisastra, J., Elya, B. (2018). Identifikasi Kandungan Saponin dalam Ekstrak Kamboja Merah (Plumeria rubra L.) dan Daya Surfaktan dalam Sediaan Kosmetik. Jurnal Kefarmasian Indonesia, 8 (2): 86

Purwati, Yossy, Marsella. (2020). Fitokimia dan Potensi Antioksidan Daun Jembelu (Embelia sp) Tanaman Obat Dari Kabupaten Kutai Kartanegara. Jurnal Agrifor XIX (1) 72-74

Rahayu, Y.D., Sutedjo, dan Matius, P. (2007)."Kajian Potensi Tumbuhan Obat Di Kawasan Malinau Research Forest (MRF) Cifor Kabupaten Malinau Kalimantan Timur". Jurnal Kehutanan UNMUL 3(1), April 2007.

Risa .S, Fatimah, N, Purwanti, YE. (2019). Karakterisasi Spesifik dan Non Spesifik Ekstrak Etanol Daun Putat (Planchonia valida), Jurnal Al Ulum Sains dan Teknologi 5(1):8

Saifudin. A, Rahayu. V, Teruna, HY. (2011). Standarisasi Bahan Obat Alam Edisi Pertama. Graha Ilmu: Yogyakarta. Hal 74.

Supomo, Supriningrum, R., Junaid, R. (2016). Karakterisasi dan Skrining Fitokimia Daun Kerehau (Callicarpa longifolia Lamk.). Jurnal Kimia Mulawarman, 13 (2): 90. 